\title{
Study on Existing Issues and Countermeasures of Accounting Information Disclosure of Listed Companies in China
}

\author{
Zhenghong Che \& Huiying Wang \\ School of Economics \& Management, Changchun University of Science \& Technology \\ Changchun 130022, China \\ E-mail: czh912@126.com
}

Received: July 6, $2011 \quad$ Accepted: August 6, $2011 \quad$ doi:10.5539/ass.v7n9p115

\begin{abstract}
Information disclosure of listed companies is of great importance to the stock market in China, because sufficient disclosure of information is an issue that calls for urgent resolution to enhance the efficiency of stock market. This article analyzes some issues existing in information disclosure of listed companies in the stock market and finally proposes countermeasures to improve information disclosure issues in the stock market in China.

Keywords: Listed company, Information disclosure, Standard, Supervision

Information disclosure of listed companies means that any information should be made public according to normative standards that might affect such information users as stockholders, creditors or potential investors' making rational judgment on the current and future operational condition of the listed companies and affect their decision making behaviors. The purpose of accounting information disclosure of listed companies is to enable information users to obtain equal necessary information, make correct decisions of investment and protect legitimate rights of investors and other interests of the social public.
\end{abstract}

\section{Significance of information disclosure to the stock market in China}

Information disclosure system, also termed as announcement system and public disclosure system, means that listed companies have to report their financial changes, information and data of their operational conditions to security administration department and stock exchange in pursuant to legal regulations in order to guarantee interests of investors and accept supervision of the social public, and make all the information and data public or announced, so as to enable investors to have a complete mastery of the situation. Information disclosure system not only includes disclosure prior to its release, but also includes continuing disclosure of information after the companies are listed, which mainly constitutes prospectus system, periodical report system and interim report system.

In the stock market, uncertainty and risk are the important factors that affect the price of the securities and that constitute characteristics of the securities. Since acquisition of information can alter evaluation on uncertainty and risks of securities, information has direction effect on and decisive significance to price fluctuation and price balance of the stock market. Only on the condition of sufficient knowledge in the relevant comprehensive information of listed companies' financial and operational activities, can rational investors make a decision and make correct judgment. Under such a circumstance, price of securities can really match with its actual value. That is to say, securities with high value obtain corresponding high price and projects with excellent quality can obtain sufficient capital, which can guarantee that the stock market is effectively operated. Thus, it can be seen, information is of critical important to the stock market. Information disclosure system is a forever persistent process in terms of the time of information disclosure and is combination of regular interval and irregular interval. According to experiences of demutualization of enterprises all over the world, the stock market is a necessary result of development of joint-stock system. Only if stockholders are provided with a system in which they can realize their shares at any time, demutualization reform can gain more extensive public foundation and get more rapidly promoted and benefits can be realized that are generated from large-scale capital.

\section{Analysis of quality factors affecting accounting information disclosure in listed companies}

\subsection{Corporate governance}

Separation and balance of proprietor and manager in corporate governance structure is the effective guarantee of 
quality of accounting information disclosure of listed companies. Deficiency of corporate governance structure in China has negative effects upon quality of accounting information disclosure, which are shown as follows: irrational ownership structure --- "domination of a single shareholder", control over accounting information by controlling shareholders at will, control by internal personnel --- board of directors not playing its due role, board of supervisors becoming a mere formality, the supervision function of accounting information disclosure not fulfilled.

\subsection{Interest driving is the internal reason for unhealthy accounting behaviors in listed companies}

In the first place, accounting information of listed companies has some characteristics of public goods. That is to say, cooperation between an accounting information demander and the information does not affect usage of other behavioral subjects. Accounting information of listed companies does not only exert great influences upon interests of the company itself and interests of the partakers having direct relation of interests with the company, but also has effects upon interests of other listed companies, other investors and security exchange and even interests of the entire stock market society. Driven by the interests, a company always performs accounting behaviors that are favorable to itself, which may cause accounting information to lose its fairness in terms of both quantity and quality and not to satisfy demands of all information users.

In the second place, the supply subjects of accounting information present a diversified pattern. In the former days, the supply subjects of accounting information are accountants (on behalf of the listed company) of a listed company, while at present, all relevant interest group (such as, sponsor, competent department of the company, and senior management personnel of the company, etc.) make every endeavor to affect supply of accounting information by the listed company, and even take an active attitude towards participating in the supply of accounting information). In this way, accounting information would be somewhat biased that is supplied through coordination.

\subsection{Information supply cost}

An important constraint for information supply is information disclosure cost. Benefit being higher than cost has always been the basic precondition for information disclosure, so information disclosure needs to take into consideration of benefit and cost. From the perspective of an enterprise, information disclosure mainly contains the two sorts of measurable cost and immeasurable cost. Measurable cost refers to information cost that can be definitely calculated and actually paid, which contains information processing cost and information auditing cost. Immeasurable cost is manifested as adverse effects of information disclosure upon enterprises, and this sort of cost does not require an enterprise to make the payment directly and is difficult to be directly measured, such as, unfavorable competition caused by information disclosure and restraint of information disclosure upon behaviors of mangers, etc.

\subsection{Attitude of government supervision}

The fact indicates that, supervision of the government on accounting information disclosure behavior of enterprises does not completely comply with demands of information users, since it is obvious that it is difficult for the former to totally understand and adapt to the latter. Thus, standing from the perspective of information users, influences of the government through rules and regulations on accounting information disclosure behaviors of enterprises might either be too large or be too small, which is always at a condition of adjustment. On the other hand, supervision of the government on accounting information disclosure behaviors of enterprises is also constrained by the costs of enterprises themselves, including organization cost, research cost, cost of supervision on enterprises and increased cost of an entire enterprise that might be caused by inappropriate measures taken. However, the disclosure behavior of enterprises is directly affected by the supervision of the government. Therefore, if the government comes to know a little bit in detail about demands of information users, the constraint of the principle of cost-benefit is a little bit smaller, and requirement on accounting information disclosure of enterprises is a little bit more compulsory, then information offered by enterprises might be more in details and more relevant.

\section{Existing issues in information disclosure of listed companies in China}

\subsection{Unserious information disclosure and improper procedures for information disclosure}

In China, there are a large majority of listed companies with strong randomness in information disclosure. There are even some listed companies that decide without authorization to issue some important information that concerns about the economic decision making of the country without approval of relevant supervision department, or bring a lot of hearsays to make a market. This seriously damages the seriousness of information disclosure system of listed companies, which is neither helpful for investors to share rights of relevant 
information of listed companies nor helpful to remind investors of paying attention to new changes of listed companies.

\subsection{Inauthentic accounting information disclosure}

Inauthentic accounting information has, so far, become the most serious problem in information disclosure in listed companies. Effectiveness of information decides effectiveness of the stock market. If the information disclosure by listed companies is inauthentic, especially if they fabricate fake information with malevolence and retain significant information on purpose, it will, without doubt, cause extremely destructive effects on the stock market, and, in the mean time, will attack the foundation of the entire stock market and even damage the reputation of listed companies.

\subsection{Untimely accounting information disclosure}

Untimely accounting information disclosure means that, listed companies intentionally waste time and don't disclose in time any significant incident that might have been predicated by them to have great influences on the stock price of listed companies and that might have not been in the knowledge of investors or that listed companies do not give any explanation or do not give timely public explanation to the reasons for external hearsay that might affect the stock price fluctuation of listed companies, which may damage the interests of investors. If someone intentionally takes advantage of this opportunity to conduct an insider trading, it might affect interests of investors to a large extent. Currently, there are mainly interim report and periodic report. However, the phenomenon of untimely information disclosure exists in either of the two kinds of reports.

\subsection{Incomplete accounting information disclosure}

Since there still exists certain hysteresis in relevant system about accounting information disclosure in China, listed companies do not perform authentic and complete disclosure to the information that should be disclosed. Instead, they avoid the important and dwell on the trivial and exaggeratedly conceal the truth of the fact, which might mislead investors in making correct judgment. As for the financial report, a large majority of listed companies lay special emphasis on information in terms of the finance, which might give rise to little disclosure of non-financial information that may have more reference value.

Some listed companies keep back the structure proportion of inventory and the cashability as well as the debt, etc., with an excuse that the "commercial secret" is not convenient to be public, which seriously threats the capital security of investors. Moreover, information about social responsibilities of employee welfare, employee education and training, environmental pollution and governance, and public benefit donation might directly affect the image of listed companies in the social public, whereas the image of listed companies in the social public might affect their value to a certain extent. In practical operation, some listed companies put their social responsibilities beneath notice and ignore social benefits.

\subsection{Inactive information disclosure}

At present, listed companies in China are at a stage of mandatory disclosure of information. The Sixty-fifth Article and the Sixty-sixth Article of "Securities Act" stipulate that, "Listed companies ought to submit interim report and annual report to the Securities Regulatory Authority of the State Council and the Securities Exchange within two months from the end of the first half of the accounting year each year and within four months from the end of the annual accounting year and also publicize the reports". It is often that listed companies regard information disclosure as extra burden, so they are reluctant to disclose relevant information in a positive and enthusiastic attitude. The reason is that there are a lot of inside stories of listed companies in their operation and management that they are unwilling to let the public know, and thus they might hold a kind of fear and escape attitude towards information disclosure.

\section{Countermeasures to complete accounting information disclosure in the listed companies}

\subsection{To perfect the corporate governance structure of listed companies and to strengthen internal control of listed companies}

Sponsors for state-owned shares of listed companies are not in place and the setting of equity structure is not rational, as a result of which the governance structure of listed companies is not rational and the three lines of defense of board of directors, board of supervisors and independent directors are unable to well prevent and control information distortion. Thus, it is necessary to reform the equity structure of listed companies. The following are practices in details: reducing state-owned shares, dispersing equity structure, reform of the property rights system of sponsors for state-owned shares so as to define the sponsors, vigorously cultivating institution investors, giving play to the balancing function of the governance structure of listed companies, 
encouraging stakeholders (especially creditors of the listed companies) to take part in corporate governance and making up for deficiency in the internal governance structure of listed companies.

\subsection{To improve construction of legal system}

In China, the court of justice only accepts and hears the false statement cases that are dealt with by CSRC (China Securities Regulatory Commission) and sets up a prepositive administrative examination procedure before a civil action is submitted. In order to alter this current condition, the government has to promulgate "Compensation Act for Civil Liability" to define who should be responsible for violation of law, refine civil liability for security violation behaviors through legislative and judicial interpretation, offer definite stipulation to determination of qualification of plaintiff and defendant, regulation of the loss scope, calculation of the quantum of damage, burden of proof and means of payment, etc., and strengthen and refine regulations on security civil liability. As for any illegal violation action of the social auditing in the process of functioning, they have to be strict in enforcing the law and any violation of the law must be investigated and dealt with.

\subsection{To build an honest and faithful social environment}

It won't work to manage the finance work just resorting to legal means. In the mean time, education of credit has to be strengthened. Those who keep their promise may get due returns and those who break their promise may get due punishment by establishing and improving rules and regulations, which helps to enhance the vigor of credit. We can also set up personal credit files by means of setting up credit files and referring to the practice of loan so as to investigate corresponding legal responsibilities for any behavior that causes negative results with malevolence.

\subsection{To standardize behaviors of certified public accountants}

It seems that there exists a kind of active and passive relationship between certified public accountants and enterprises, which is that, sometimes, certified public accountants have to present false auditing reports, while most of their auditing reports are primary evidence for the vast majority of investors to make a decision. Therefore, we have to enhance the occupational level and occupational quality of certified public accountants, standardize business competition between different accounting firms, increase popular trust and remuneration of certified public accountants, speed up in promulgating the law for certified public accountants and improve quality of auditing.

\subsection{To enhance quality of accountants in enterprises}

Improvement of the occupational morality and comprehensive quality of accountants in enterprises can effectively guarantee implementation of accounting information disclosure system. We can carry out the improvement from the following three aspects. Firstly, we ought to intensify the professional quality of accountants, strictly put into practice evaluation in the new accounting law on occupational qualification for financial management persons and accountants, work out scientific occupational morality rules for accountants and put these rules into practice with strict rewards and punishment policies. Secondly, we ought to perfect education of credit among accountants and cultivate and mould the occupational morality of accountants. Management personnel of enterprises take the responsibility for the accounting work in the enterprises and the accountants assume the important obligation of carrying out the "Accounting Law". Thirdly, inauthentic accounting information that often occurs in the enterprises is not only behavior of accountants. Education of accounting credit should be overall and holistic education for accountants and social auditing institutes.

\section{References}

Li, Fengtuan. (2010). Establishment of Accounting Information Disclosure System of Corporate Social Responsibility. Commercial Accounting, (17).

Wan, Shan. (2009). Problems and Countermeasures in Accounting Information Disclosure in Listed Companies. Journal of Hunan University of Science and Engineering, 2.

Yu, Tianye. (2009). Issues and Countermeasures in Accounting Information Disclosure in Listed Companies. Business Modernization, 2.

Zha, Ruiping. (2006). Discussion on Issues in Accounting Information Disclosure in Listed Companies. Shandong Commercial Accounting, (1).

Zheng, Jun. (2007). Humble Opinions on Information Disclosure System in Listed Companies. Economic \& Trade Update, (1). 